J. Amer. Soc. Hort. Sci. 119(1):110-115. 1994.

\title{
Nuclear DNA Content and Ploidy Levels in the Genus Ipomoea
}

\author{
Peggy Ozias-Akins ${ }^{1}$ \\ Department of Horticulture, University of Georgia Coastal Plain Experiment Station, Tifton, GA 31793
}

Robert L. Jarret

U.S. Department of Agriculture-Agricultural Research Service, Regional Plant Introduction Station, Griffin, GA 30223

Additional index words. DAPI, genome size, sweetpotato

\begin{abstract}
The nuclear DNA content of 53 accessions from 24 Ipomoea (Convolvulaceae) species, including four sweetpotato cultivars, was determined by flow cytometry of DAPI-stained nuclei. Ploidy level and DNA content were significantly correlated within the genus, but more highly so within species that contained multiple cytotypes. DNA content of cultivated Z. batatas (L.) Lam. (4.8 to $5.3 \mathrm{pg} / 2 \mathrm{C}$ nucleus) and feral tetraploid I. batatas (3.0 to $3.5 \mathrm{pg} / 2 \mathrm{C}$ nucleus) was estimated from the known DNA content of chicken erythrocytes $(2.33 \mathrm{pg})$, which were used as an internal standard. Tetraploid forms of Z. cordato-triloba Dennstedt also were identified. Ploidy analysis using flow cytometry is rapid and suitable for large-scale experiments such as studying the genetic structure of populations of $\mathbf{Z}$. batatas and related species. Chemical name used: 4',6-diamidino-2-phenylindole (DAPI).
\end{abstract}

Nuclear DNA content can be used to estimate ploidy level, provided that there has been sufficient cytological investigation to base the study on known chromosome numbers and ploidy ranges. The quantitation of DNA content often has been based on microspectrophotometry of Feulgen-stained nuclei in squashed tissues (Bennett and Smith, 1976; Bennett et al., 1982). This method requires careful standardization of tissue samples and fixation, reaction, and spectrophotometer conditions (Price, 1988). More recently, flow cytometry of nuclei stained with DNA fluorochromes has been recognized as a fast, accurate alternative to microspectrophotometry (Dolezel, 1991; Galbraith, 1989). A strong correlation between DNA values determined by Feulgen microspectrophotometry and flow cytometry has been shown (Michelson et al., 1991). The flow cytometer uses a laser beam that is focused on a small sample stream containing suspended nuclei. The nuclei can be stained with DNA fluorochromes such as ethidium bromide or propidium iodide (intercalating dyes), DAPI (specific for A-T base pairs), and mithramycin (specific for G-C base pairs). Computer-assisted measurements of fluorescence emission per fluorescent particle allow the generation of a histogram reflecting the distribution of fluorescence intensity among a fixed number of particles. Several thousand particles can be measured within minutes by flow cytometry, which has a capacity of at least two orders of magnitude greater than that of microspectrophotometry.

The genus Ipomoea (Convolvulaceae) is thought to contain $>500$ species with known ploidy levels of $2 x, 4 x$, and $6 x$ and a basic chromosome number of $x=15$ (Jones, 1964, 1968). The high basic chromosome number and small chromosome size in species of this genus make cytological studies laborious and time consuming. Morphological plasticity within the genus has led to considerable

Received for publication 21 Oct. 1992. Accepted for publication 22 Apr. 1993. This work was funded by a grant from the Univ. of Georgia Research Foundation and from state and Hatch funds allocated to the Georgia Agricultural Experiment Stations. We thank Al Jones, Mel Hall, and Carole Bassett for providing germplasm. We also thank Craig Sheppard for the chicken blood, Julie Golden for technical assistance with the flow cytometer and data output, and Richard Layton for assistance with statistical analysis. The cost of publishing this paper 'was defrayed in part by the payment of page charges. Under postal regulations, this paper therefore must be hereby marked advertisement solely to indicate this fact. To whom reprint requests should be addressed. confusion in the systematic classification of many species (Austin, 1988). Further confusion results from the existence of polyploid complexes in some section Batatas species; e.g., Z. trifida and $I$. batatas (Austin, 1988).

Polyploid complexes in plants are common (Harlan and DeWet, 1975). Existing populations of some Ipomoea species likely are mixtures of diploid, triploid, tetraploid, and hexaploid members (Kobayashi, 1984; Nishiyama, 1971; Shiotani and Kawase, 1989). The crossability of 2x and 4x I. trifida cytotypes (Iwanaga et al., 199 1) and documented $2 \mathrm{n}$ pollen formation in 2x and 4x I. trifida cytotypes (Orjeda et al., 1990) and feral Z. batatas (Jones, 1990), respectively, provide a mechanism for the generation of triploid and hexaploid forms of these species. Tetraploid and hexaploid forms of I. batatas are known to occur (Austin, 1988; Jarret et al., 1992). Because population studies require many individuals, the most reasonable and timely method for comparing ploidy levels within populations is flow cytometry. In this report on Ipomoea species, we show that ploidy level and DNA content, as estimated by flow cytometry, are highly correlated, especially within a species, and we suggest that population-scale studies are now feasible.

\section{Materials and Methods}

Plant material. Accessions of Ipomoea species used in this study were obtained from sources listed in Table 1. Plants were grown in the greenhouse in pots from which one to three plants of each accession were sampled for further processing.

Nuclei isolation. Young leaves from greenhouse-grown material were collected and stored on ice until processed. Leaves were chopped with a double-edged razor blade in a $10-\mathrm{cm}$ sterile petri dish with $\approx 2 \mathrm{ml}$ buffer (Dolezel et al., 1989). Chopping buffer consisted of $15 \mathrm{~mm}$ tris- $\mathrm{HCl}$ (pH 7.5), 2 mu EDTA, $80 \mathrm{~mm} \mathrm{KCl,} 20$ $\mathrm{mm} \mathrm{NaCl}, 0.5 \mathrm{~mm}$ spermidine, $15 \mathrm{~mm} \beta$-mercaptoethanol, and $0.1 \%, 0.5 \%, 1.0 \%$, or $2.0 \%$ detergent (Triton X-100; Sigma, St. Louis). All components-except spermidine, B-mercaptoethanol, and detergent-were combined and sterilized in an autoclave. Heat-labile components were added after autoclaving. Chopped leaf tissue was scraped into the center of the tilted petri dish and an additional $3 \mathrm{ml}$ buffer was added slowly to rinse the chopped tissue. Buffer containing released nuclei was filtered through 60- 
$\mu \mathrm{m}$ nylon mesh that had been heat-fused to the cut tip of a disposable 5-ml plastic pipette. Eight samples were processed and accumulated on ice before being centrifuged.

Nuclei were pelleted in conical centrifuge tubes by spinning the samples at $3000 \times \mathrm{g}$ for $5 \mathrm{~min}$ at $4 \mathrm{C}$. The pellet was resuspended by tapping the tube, and $1 \mathrm{ml}$ of fixative (one part $0.9 \% \mathrm{NaCl}$ to one part absolute ethanol; Hülgenhof et al., 1988) was added in small aliquots and mixed after each addition. Nuclei were fixed for 15 to $30 \mathrm{~min}$ at $4 \mathrm{C}$ and subsequently pelleted in microcentrifuge tubes. Fixed nuclei were resuspended in $96 \%$ ethanol and stored at $4 \mathrm{C}$.

Flow cytometry. Immediately before flow cytometry, nuclei were pelleted by a brief spin and resuspended in 250 to $1500 \mu \mathrm{l}$ staining buffer (Sgorbati et al., 1988) to give a roughly equivalent, visually estimated turbidity. The staining buffer consisted of 10 mM tris- $\mathrm{HCl}$ (pH 7.4), 10 mM EDTA, $100 \mathrm{~mm} \mathrm{NaCl}, 0.1 \%$ Triton $\mathrm{X}-100$, and $5.6 \mu \mathrm{M}$ DAPI. Nuclei were stained for $30 \mathrm{~min}$. Relative fluorescence was measured with a flow cytometer (model EPICS 753; Coulter Corp., Hialeah, Fla.) set for ultraviolet excitation and fluorescence collection with a 418-nm long-pass filter. DNA content was estimated using chicken erythrocytes (from White Leghorn hens, fixed and stained as described above for plant nuclei) as an internal standard. In some cases, the plant 2C DNA peak and the Singlet chicken erythrocyte peak coincided precisely. An internal standard, therefore, was not included with unknowns; instead, a chicken erythrocyte sample was stained at the same time as each plant sample and run after every fourth or fifth plant sample to determine if any instrument drift had occurred. A value of 2.33 pg was assigned to the singlet peak of chicken erythrocytes (Galbraith et al., 1983) and was used to calculate the DNA content of all plant samples.

Statistical analysis. SAS's General Linear Models Procedure (SAS Institute, Cary, N.C.) was used to verify that experimental procedures were not a significant source of variation. Subsequently, analysis of variance was conducted to determine effects of ploidy level, species within the same ploidy level, and genotypes within a species. Only those species with known ploidy levels were included in the analysis. Mean separation of DNA content within ploidy level was carried out with Tukey's studentized range test.

\section{Results and Discussion}

Nuclei isolation. Higher-quality nuclear preparations were obtained from 50 to $100 \mathrm{mg}$ of tissue, usually three to six leaves, than from larger quantities. Young leaves that were not fully expanded were superior to mature leaves as a source of nuclei. For Ipomoea species, leaves that were still folded or had just unfolded were ideal. Preliminary experiments with the chopping buffer of Galbraith et al. (1983), which contains 0.170 Triton X-100 detergent, did not give good results. The chopping buffer of Dolezel et al. (1989) with Triton X-100 detergent concentrations of $0.1 \%, 0.5 \%, 1 \%$, and $2 \%$, was subsequently tested on I. batatas 'Red Jewel'. The CV was greater for the $2 \mathrm{C}$ peak of nuclei isolated in $0.1 \%$ detergent $(8.3$ and 8.4) than for nuclei from higher detergent concentrations $(0.5 \%$ and $1 \%$, CVs 6.3 and $6.9 ; 2 \%$, CVs 4.5 and 6.4). From the distribution of fluorescence intensity, it also was apparent that debris or organelle contamination of the nuclear preparation was greater at the lowest detergent concentration. The $2 \mathrm{C}$ peak was consistent among both replicates of $0.5 \%$ and $1 \%$ detergent; thus, $1 \%$ detergent was selected for all subsequent experiments.

Free nuclei can be isolated by finely chopping plant tissues or by lysing protoplasts in buffers containing a detergent, usually Triton X-100. The most frequently used detergent concentration has been $0.1 \%$; however, nuclei could be isolated from Vitis vinifera $\mathrm{L}$. only after increasing the concentration to $2 \%$ (Dolezel et al., 1989). We also found it necessary to increase the detergent concentration to $>0.170$ to maintain consistent quality of nuclear preparations from Ipomoea species when using the same chopping buffer as for grape.

DNA content. Mean relative fluorescence of the prominent G1 peak was used to estimate DNA content relative to the DAFI-stained chicken erythrocyte standard (Table 1, Fig. 1). The 2C peak for $I$. nil (Pharbitis nil Chois.) coincided with the chicken erythrocyte singlet peak in three experiments and had a DNA content of 2.33 pg. Hirano et al. (1989) measured a DNA content in DAPI-stained nuclei of $P$. nil of $10^{\circ} \mathrm{bp} /$ haploid genome or, when converted, $1 \mathrm{pg} /$ haploid genome. This value is close to what we obtained in our experiments (1. $15 \mathrm{pg} /$ haploid genome). One other species, $\mathrm{Z}$. littorals, showed a DNA content similar to that of I. nil. Previously published DNA values for Ipomoea include I. purpurea $(1.08 \mathrm{pg} /$ 2C nucleus; Galbraith et al., 1983) and I. batatas (3.31 pg/2C; Arumuganathan and Earle, 1991a, 1991 b). In these reports, $I$. purpurea nuclei were stained with mithramycin, whereas I. batatas nuclei were stained with propidium iodide; both were compared with chicken erythrocytes as internal standards. Our estimated absolute DNA values for both species were higher than values in either previously published report. Nevertheless, our estimated DNA amounts were consistent for species run over several experiments; I. batatas 'Red Jewel' gave an estimated DNA content of 4.5 to 4.8 over four experiments; over these experiments, percentage $\mathrm{CV}$ equaled 5.5,5.6,5.6, and 7.6. The percentage $\mathrm{CV}$ for chicken erythrocytes ranged from 5.0 to 5.6, which was similar to the $\mathrm{CV}$ of the plant samples. Over all species with replicated samples, a certain amount of variation occurred between experiments, but the variation usually was within the standard deviation of the measurements.

There could be several possible explanations for the differences in previously reported DNA values and our results. We assayed fixed (not fresh) nuclei, used a substantially different chopping buffer and higher detergent concentration, and used a different DNA fluorochrome (DAPI). Propidium iodide and DAPI are the most commonly used fluorochromes for flow cytometric DNA analysis. The DNA fluorochrome of choice is controversial (Galbraith, 1989; Michelson et al., 1991; Raybum et al., 1989), mainly because of the different interactions with DNA (i.e., base-independent intercalation vs. binding to specific nucleotide base-pairs), but also because various staining conditions sometimes can alter affinity (Dolezel, 1991). Propidium iodide and DAPI typically give CVS of $<5 \%$, a level that is required for cellcycle analysis. Slightly higher CVs obtained in our experiments may have resulted from the fixation method or instrument error but can be tolerated for ploidy determination. Fixation is necessary when flow cytometry must be conducted at a distant site and when material is not synchronized or must be collected from various locations. The ability to fix and accumulate samples makes large-scale experiments more feasible. Flow cytometric analysis of all samples on the same day or replication of the same samples on different days also is desirable to reduce instrument and experimental error (Vindelov et al., 1982).

Variation between DNA content measurements within a species could be attributed to several factors. True variation within a species has been documented well (Laurie and Bennett, 1985; Raybum and Auger, 1990), and different DNA content values reported in the literature could have resulted partly from sampling different genotypes. Instrument or operator variance during nuclear isolation and analysis also could be responsible for different measured values. Although the source of variation is unknown in 


\begin{tabular}{|c|c|c|c|c|c|}
\hline Genotype & Ipomoea & Origin & Source $^{\mathrm{z}}$ & Ploidy & $\begin{array}{l}\text { DNA content } \\
\text { (pg/2C nucleus) }\end{array}$ \\
\hline 538264 & argillicola R.W. Johnson & Australia & G & $4 x^{y}$ & 3.0 \\
\hline 81.2 & batatas (H.B.K.) G. Don & Ecuador & $\mathrm{C}$ & $4 x$ & 3.5 \\
\hline 518473 & batatas (L.) Lam. & Mexico & $\mathrm{G}$ & $4 x$ & 3.4 \\
\hline 518474 & batatas (L.) Lam. & Mexico & $\mathrm{G}$ & $4 \mathrm{x}$ & 3.0 \\
\hline 518476 & batatas (L.) Lam. & Mexico & $\mathrm{G}$ & $4 \mathrm{x}$ & 3.2 \\
\hline 518478 & batatas (L.) Lam. & Mexico & $\mathrm{G}$ & $4 \mathrm{x}$ & 3.2 \\
\hline DLP 5283 & batatas (L.) Lam. & Ecuador & $\mathrm{G}$ & $4 x^{y}$ & 3.1 \\
\hline A7817 & batatas (L.) Lam. & Ecuador & $\mathrm{G}$ & $4 x^{y}$ & 3.5 \\
\hline Red Jewel & batatas (L.) Lam. & United States & $\mathrm{T}$ & $6 x$ & 4.8 \\
\hline Copper Resisto & batatas (L.) Lam. & United States & $\mathrm{G}$ & $6 \mathrm{x}$ & 5.2 \\
\hline Coastal Red & batatas (L.) Lam. & United States & $\mathrm{T}$ & $6 x$ & 4.5 \\
\hline GA Red & batatas (L.) Lam. & United States & $\mathrm{T}$ & $6 x$ & 4.6 \\
\hline 62.19 & cordato-triloba Dennstedt & United States & $\mathrm{C}$ & $2 \mathrm{x}$ & 1.7 \\
\hline 80.6 & cordato-triloba Dennstedt & United States & $\mathrm{C}$ & $2 x$ & 1.7 \\
\hline 540710 & cordato-triloba Dennstedt & Colombia & $\mathrm{G}$ & $2 \mathrm{x}$ & 1.7 \\
\hline 72.2 & cordato-triloba Dennstedt & United States & $\mathrm{C}$ & $2 \mathrm{x}$ & 1.8 \\
\hline MC1310 & cordato-triloba Dennstedt & Mexico & $\mathrm{G}$ & $2 \mathrm{x}$ & 1.6 \\
\hline MC1961 & cordato-triloba Dennstedt & Mexico & $\mathrm{G}$ & $4 x$ & 3.0 \\
\hline MC1984 & cordato-triloba Dennstedt & Mexico & $\mathrm{G}$ & $4 x$ & 3.3 \\
\hline 518495 & cordato-triloba Dennstedt & Mexico & $\mathrm{G}$ & $4 \mathrm{x}$ & 3.3 \\
\hline 549093 & cynanchifolia Meisn. & Brazil & G & $2 \mathrm{x}$ & 1.7 \\
\hline 63.36 & lacunosa $\mathrm{L}$. & United States & G & $2 \mathrm{x}$ & 1.7 \\
\hline 85.27 & lacunosa $\mathrm{L}$. & United States & $\mathrm{C}$ & $2 \mathrm{x}$ & 1.5 \\
\hline 62.82 & lacunosa $\mathrm{L}$. & United States & $\mathrm{C}$ & $2 \mathrm{x}$ & 1.6 \\
\hline 78.19 & lacunosa L. & United States & $\mathrm{C}$ & $2 \mathrm{x}$ & 1.8 \\
\hline 536036 & xleucantha Jacq. & Mexico & G & $2 \mathrm{x}$ & 1.6 \\
\hline Q27809 & littoralis Blume & Australia & G & $2 x$ & 2.4 \\
\hline 538274 & muelleri Benth. & Australia & $\mathrm{G}$ & $2 x-4 x^{y}$ & 2.7 \\
\hline 540706 & nil (L.) Roth. & Colombia & G & $2 x$ & 2.3 \\
\hline Violet & nil (L.) Roth. & Japan & A & $2 \mathrm{x}$ & 2.3 \\
\hline 530993 & obscura (L.) Ker-Gawl. & Dominican Republic & G & $2 x-4 x^{y}$ & 2.6 \\
\hline 518482 & pedatisecta Mart. & Mexico & G & $2 \mathrm{x}$ & 1.6 \\
\hline 549258 & pes-tigridus L. & Australia & G & $2 \mathrm{x}$ & 2.0 \\
\hline 171664 & purpurea (L.) Roth. & Turkey & G & $2 \mathrm{x}$ & 2.0 \\
\hline 87.3 & ramosissima (Poir.) Choisy & Peru & $\mathrm{C}$ & $2 \mathrm{x}$ & 1.7 \\
\hline 518483 & sp. & Mexico & $\mathrm{G}$ & $4 x^{y}$ & 3.0 \\
\hline 71.9 & sagittata Poir. & United States & $\mathrm{G}$ & $2 x-4 x^{y}$ & 2.7 \\
\hline $\mathrm{J} 7257$ & saintronanensis $\mathrm{R} . \mathrm{W}$. Johnson & Australia & G & $4 x^{y}$ & 3.3 \\
\hline 518479 & tabascana McDonald \& Austin & Mexico & G & $4 x$ & 2.6 \\
\hline 87.4 & tenuissima Choisy & United States & $\mathrm{C}$ & $2 \mathrm{x}$ & 1.8 \\
\hline 518488 & tiliacea (Will.) Choisy & Mexico & G & $4 \mathrm{x}$ & 4.0 \\
\hline 540723 & trifida (H.B.K.) G. Don & Colombia & G & $2 \mathrm{x}$ & 1.7 \\
\hline 74.1 & trifida (H.B.K.) G. Don ${ }^{\mathrm{x}}$ & Unknown & $\mathrm{C}$ & $2 \mathrm{x}$ & 1.7 \\
\hline 87.2 & trifida (H.B.K.) G. Don ${ }^{\mathrm{x}}$ & Ecuador & $\mathrm{C}$ & $4 \mathrm{x}$ & 3.4 \\
\hline 80.3 & trifida (H.B.K.) G. Don ${ }^{x}$ & Mexico & $\mathrm{C}$ & $4 \mathrm{x}$ & 3.4 \\
\hline 79.5 & trifida (H.B.K.) G. Don ${ }^{\mathrm{x}}$ & Mexico & $\mathrm{C}$ & $4 \mathrm{x}$ & 3.4 \\
\hline 72.4 & trifida (H.B.K.) G. Don ${ }^{x}$ & Mexico & $\mathrm{C}$ & $4 x$ & 3.6 \\
\hline 530997 & triloba $\mathrm{L}$. & Dominican Republic & $\mathrm{G}$ & $2 \mathrm{x}$ & 1.6 \\
\hline 62.85 & triloba $\mathrm{L}$. & Unknown & $\mathrm{C}$ & $2 \mathrm{x}$ & 1.5 \\
\hline 67.66 & triloba $\mathrm{L}$. & Caribbean & $\mathrm{C}$ & $2 \mathrm{x}$ & 1.6 \\
\hline 530999 & triloba $\mathrm{L}$. & Dominican Republic & $\mathrm{G}$ & $2 \mathrm{x}$ & 1.7 \\
\hline 1989 & umbraticola House & Mexico & G & $2 \mathrm{x}$ & 1.7 \\
\hline 518496 & wrightii A. Gray & Mexico & $\mathrm{G}$ & $2 x^{y}$ & 2.0 \\
\hline
\end{tabular}

$\overline{{ }_{z}} \mathrm{G}=$ Robert Jarret, U.S. Dept. of Agriculture (USDA)-Agricultural Research Service (ARS), Plant Introduction Station, Griffin, Ga. (Jarret et al., 1990); $\mathrm{C}=\mathrm{Al}$ Jones (retired), USDA, Vegetable Lab, Charleston, S. C.; T = Mel Hall, Coastal Plain Experiment Station, Tifton, Ga.; A = Carole Bassett, USDA-ARS, Russell Laboratory, Athens Ga.

${ }^{\text {y}}$ Ploidy level estimated by flow cytometry.

${ }^{\mathrm{x}}$ These accessions currently are being reevaluated for taxonomic classification as either I. trifida or I. batatas (J. Bohac, personal communication). 

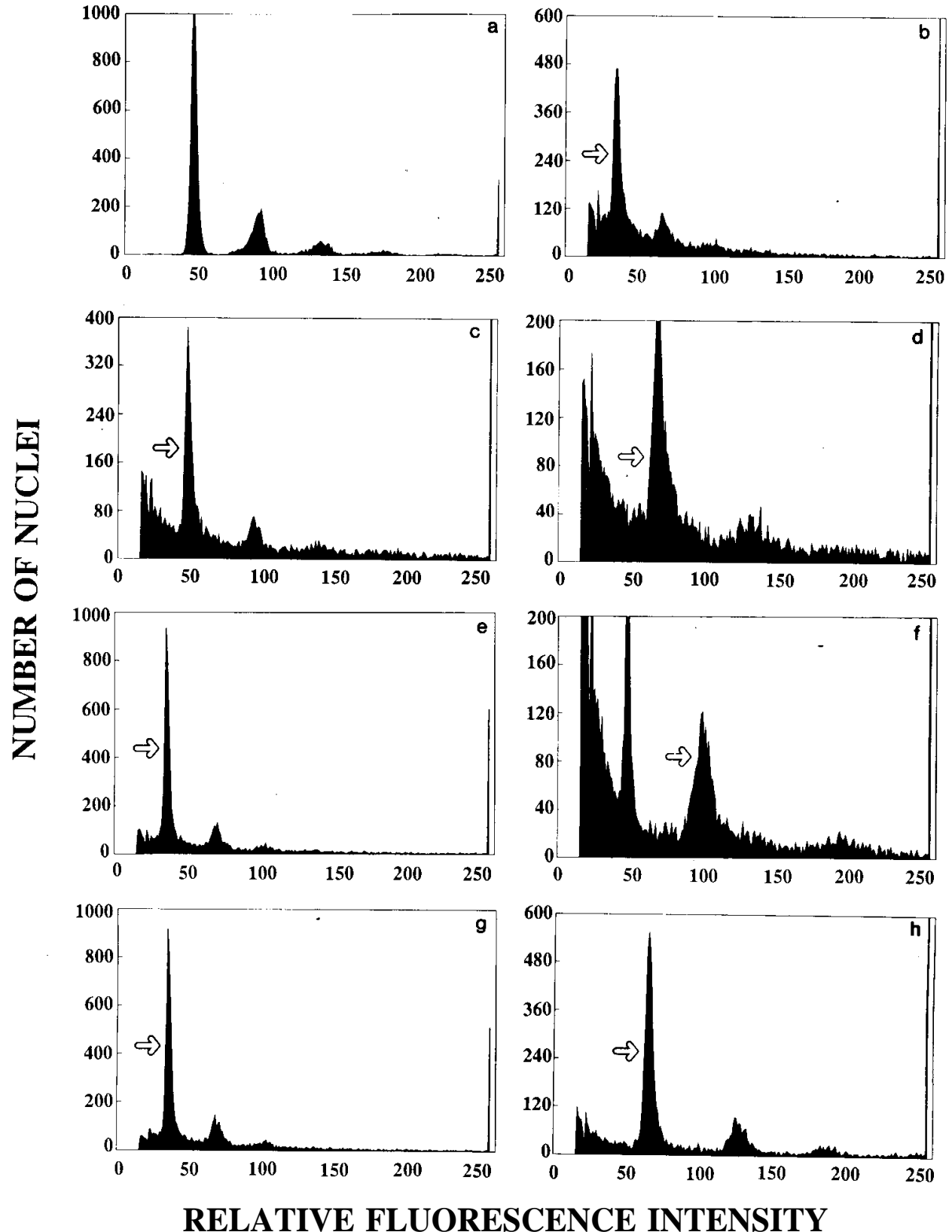

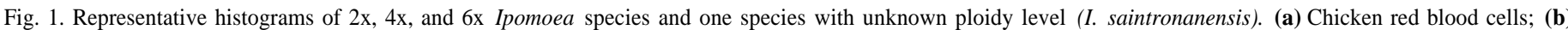
I. trifida, 2x (540723); (c) I. littoralis, 2x (Q27809); (d) I. batatas, 4x (518473); (e) I. ramosissima, 2x (87.3); (f) chicken red blood cells (mean RFI = 47) and I. batatas, 6x ('Red Jewel', mean RFI =97); (g) I. triloba, 2x (530999); (h) I. saintronanensis (J7257). Peaks of relative fluorescence intensity next to arrows represent the 2C DNA peak. Note that scales differ among subfigures.

the following example, DNA content measurements by two groups (Arumuganathan and Earle, 1991a; Michelson et al., 1991), both using propidium iodide as the DNA fluorochrome, gave differences in 2C DNA amounts as high as 1 pg for Helianthus annuus L. and Gossypium hirsutum L. Finally, within-plant differences also have been reported as developmental modifications (Bassett et al., 1988; Bassi, 1990; Cavallini and Natali, 1991). Conceivably, the estimation of DNA content in different organs could be the source of some reported variation.

Ploidy estimation. In our experiments, differences in ploidy explained most of the observed variation (Table 2). Within a ploidy level, Tukey's studentized range test showed no significant differences among diploid species, but revealed significant differences among the reportedly tetraploid species at $\mathrm{P} \leq 0.05$ (Table 3 ). The overall correlation between DNA content and ploidy level was high $(r=0.92)$. The ploidy level of several accessions that we tested was unknown but could be estimated from the measured DNA contents for most species (Table 1). For the three species with known multiple ploidy levels (I. trifida, $2 \mathrm{x}-4 \mathrm{x} ; I$. cordato-triloba, $2 \mathrm{x} 4 \mathrm{x} ;$ I. batatas, $4 \mathrm{x}-6 \mathrm{x})$ the correlation between ploidy level and DNA content was even higher $(r=0.96)$ than the overall correlation. One group of two species (Z. nil, Z. littorals) had the highest DNA content of all diploid species, and one species (I. tiliacea) had the highest DNA content of known tetraploids, which was significantly different from the other tetraploids (Table 3 ). Not unexpectedly, we found some significant differences among species within the same ploidy level. Significant variation in DNA content previously has been observed among genotypes within a species at a single ploidy level, for example in Zea mays L. (Laurie and Bennett, 1985; Raybum and Auger, 1990) and 
Table 2. Analysis of variance for effects of ploidy level and species

\begin{tabular}{lcrcc}
\hline \hline & $\begin{array}{l}\text { Type III } \\
\text { sums of }\end{array}$ & & Mean & F \\
Variable & squares & df & square & value \\
\hline Ploidy & 14.928 & 2 & 7.464 & $106.6^{* * * *}$ \\
Species & 35.535 & 19 & 1.870 & $26.7^{* * *}$ \\
Residual & 2.485 & 34 & 0.070 & \\
\hline
\end{tabular}

*** Significant at $P \leq 0.001$

Table 3. Tukey's studentized range test used to separate mean DNA content of various Ipomoea species within a ploidy level. DNA content separation within each ploidy group at $P \leq 0.05$.

\begin{tabular}{lcc}
\hline \hline & $\begin{array}{c}\text { No. of } \\
\text { accessions }\end{array}$ & $\begin{array}{c}\text { Mean } \\
\text { DNA content } \\
\text { (pg/2C nucleus) }\end{array}$ \\
\hline Diploid & \\
littorals & 1 & $2.4 \mathrm{a}$ \\
nil & 1 & $2.3 \mathrm{a}$ \\
purpurea & 1 & $2.0 \mathrm{a}$ \\
wrightii & 1 & $2.0 \mathrm{a}$ \\
ramosissima, & 1 & $1.7 \mathrm{a}$ \\
cynanchifolia & 1 & $1.7 \mathrm{a}$ \\
umbraticola & 1 & $1.7 \mathrm{a}$ \\
$\times$ leucantha & 1 & $1.6 \mathrm{a}$ \\
pedatisecta & 1 & $1.6 \mathrm{a}$ \\
triloba & 4 & $1.6 \mathrm{a}$ \\
tenuissima & 2 & $1.8 \mathrm{a}$ \\
trifida & $1.7 \mathrm{a}$ \\
lacunosa & $1.6 \mathrm{a}$ \\
pes-tigridus & $2.0 \mathrm{a}$ \\
cordato-triloba & 4 & $1.7 \mathrm{a}$ \\
tiliacea & 1 & \\
trifida & 9 & $4.0 \mathrm{a}$ \\
batatas & Tetraploid & $3.5 \mathrm{~b}$ \\
cordato-triloba & 1 & $3.2 \mathrm{bc}$ \\
tabascana & 9 & $3.2 \mathrm{bc}$ \\
\hline & 5 & $2.6 \mathrm{c}$ \\
\hline
\end{tabular}

Festuca arundinacea Schreber(Ceccarelli et al., 1992). Variation, irrespective of ploidy differences, often is attributed to repetitive DNA sequences. The slightly higher 2C DNA content for I. nil than for most diploid Ipomoea species could be due in part to the presence of a highly repeated DNA sequence family in the ribosomal DNA intergenic spacer region (Katyama et al., 1992).

DNA values reported in the present study showed a high correlation with ploidy level, particularly within a species with different cytotypes. Ploidy analysis using flow cytometry has been useful for assessing the genetic structure of natural populations of Andropogon gerardii Vitman (Keeler et al., 1987) and Vaccinium species (Ortiz et al., 1992) and synthetic populations of Beta vulgaris L. (de Laat et al., 1987). The accessions used in our study comprise many of the Closest relatives of cultivated hexaploid sweetpotato that currently are included in section Batatas. Recent revisions and additions to section Batatas have been made by Austin (1988) and McDonald and Austin (1992). Our data indicate that the I. batatas accessions from Ecuador (DLP 5283, A7817), previously described by Austin (1982), are tetraploid. This confirms an earlier report by Jarret et al. (1992), who identified the tetraploid nature of these feral sweetpotato forms and the tetraploid nature of I. tabascana by examining mitotic root-tip preparations.
Genotypes 518473 and 518474, identified as I. batatas var. apiculata (McDonald and Austin, 1992), also had a DNA content characteristic of tetraploid I. batatas. Our data indicate the existence of a polyploid complex within I. cordato-triloba. To our knowledge, this is the first report of tetraploid forms of this species. Root-tip chromosome counts of I. cordato-triloba 518495 (data not shown) revealed $2 n=4 x=60$, a configuration that agrees with our flow cytometric estimation of $3.3 \mathrm{pg} \mathrm{DNA} / 2 \mathrm{C}$ nucleus.

In conclusion, ploidy levels of different species initially should be determined cytologically due the significant differences in DNA content that have been observed at a single ploidy level. However, population-size studies subsequently could be conducted with flow cytometry to differentiate ploidy levels within a species, since there is a high correlation between DNA content and ploidy within a species. Flow cytometric studies of several species within section Batatas could be valuable for elucidating the genetic structure of natural populations and characterizing synthetic hybrids.

\section{Literature Cited}

Arumuganathan, K. and E.D. Earle. 199 la. Nuclear DNA content of some important plant species. Plant Mol. Biol. Rptr. 9:208-218.

Arumuganathan, K. and E.D. Earle. 1991b. Estimation of nuclear DNA content of plants by flow cytometry. Plant Mol. Biol. Rptr. 9:229-233.

Austin, D.F. 1982. Convolvulaceae. vol. 15. In: G. Harling and B. Sparre (eds.). Flora of Ecuador. Swedish Res. Council, Stockholm.

Austin, D.F. 1988. The taxonomy, evolution and genetic diversity of sweet potatoes and related wild species, p. 27-60. In: P. Gregory (cd.). Exploration, maintenance, and utilization of sweet potato genetic resources. Intl. Potato Ctr., Lima, Peru.

Bassett, C.L., J.R.Y. Rawson, and J.A. Jernstedt. 1988. DNA and RNA levels in bundle sheath and mesophyll cells of pearl millet (Pennisetum americanum). Plant Physiol. 87:307-310.

Bassi, P. 1990. Quantitative variations of nuclear DNA during plant development: A critical analysis. Biol. Rev. 65:185-225.

Bennett, M.D. and J.B. Smith. 1976. Nuclear DNA amounts in angiosperms. Philosophical Trans. Royal Sot. London. Ser. B 274:227-274.

Bennett, M. D., J.B. Smith, and J.S. Heslop-Harrison. 1982. Nuclear DNA amounts in angiosperms. Proc. Royal SW. London. Ser. B 216: 179-199.

Cavallini, A. and L. Natali. 1991. Intraspecific variation of nuclear DNA content in plant species. Caryologia 44:93-107.

Ceccarelli, M., E. Falistocco, and P.G. Cionini. 1992. Variation of genome size and organization within hexaploid Festuca arundinacea. Theoretical Applied Genet. 83:273-278.

de Laat, A. M. M., W. Gohde, and M.J.D.C. Vogelzang. 1987. Determination of ploidy of single plants and plant populations by flow cytometry. Plant Breeding 99:303-307.

Dolezel, J. 1991. Flow cytometric analysis of nuclear DNA content in higher plants. Phytochem. Anal. 2:143-54.

Dolezel, J., P. Binarova, and S. Lucretti. 1989. Analysis of nuclear DNA content in plant cells by flow cytometry. Biol. Plant. 31:113-120.

Galbraith, D.W. 1989. Analysis of higher plants by flow cytometry and cell sorting. Intl. Rev. Cytol. 116:165-228.

Galbraith, D. W., K.R. Harkins, J.M. Maddox, N.M. Ayres, D.P. Sharma, and E. Firoozabady. 1983. Rapid flow cytometric analysis of the cell cycle in intact plant tissues. Science 220:1049-1051.

Harlan, J.R. and J.M. DeWet. 1975. On Ö winge and a prayer: The origins of polyploidy. Bet. Rev. 41:361-90.

Hirano, H., Y. Komeda, and T. lino. 1989. Cloning and structural analysis of the snap-back DNA of Pharbitis nil. Plant Mol. Biol. 12:235-244.

Hülgenhof, E., R.A. Weidhase, R. Schlegel, and A. Tewes. 1988. Flow cytometric determination of DNA content in isolated nuclei of cereals. Genome 30:565-569.

Iwanaga, M., R. Freyre, and G. Orjeda. 1991. Use of Ipomoea trifida (HBK.) G. Don germplasm for sweet potato improvement. I. Development of synthetic hexaploids of I. trifida by ploidy-level manipulations. Genome 34:201-208. 
Jarret, R. L., N. Gawel, and A. Whittemore. 1992. Phylogenetic relationships of the sweetpotato [Ipomoea batatas (L.) Lam.]. J. Amer. Soc. Hort. Sci. 117:633-637.

Jarret, R. L., M. Spinks, G. Lovell, and A.G. Gillaspie. 1990. The S-9 plant germplasm collection at Griffin, Ga. Diversity 6:23-25.

Jones, A. 1964. Chromosome numbers in the genus Ipomoea. J. Hered. 55:216-219.

Jones, A. 1968. Chromosome numbers in the genus Ipomoea and related genera. J. Hered. 59:99-102.

Jones, A. 1990. Unreduced pollen in a wild tetraploid relative of sweetpotato. J. Amer. Soc. Hort. Sci. 115:5 12-516.

Katyama, S., H-Y. Hirano, H. Tsukaya, S. Naito, and Y. Komeda. 1992. Analysis of intergenic spacer regions in the nuclear rDNA of Pharbitis nil. Genome 35:92-97.

Keeler, K.H., B. Kwankin, P.W. Barnes, and D.W. Galbraith. 1987. Polyploid polymorphism in Andropogon gerardii. Genome 29:374-379. Kobayashi, M. 1984. The Ipomoea trifida complex closely related to sweet potato, p. 21-26. In: S.F. Shideler and H. Rincon (cd.). Proc. VIth Intl. Symp. Trop. Root Crops, Lima, Peru.

Laurie, D.A. and M.D. Bennett. 1985. Nuclear DNA content in the genera Zea and Sorghum. Intergeneric, interspecific and intraspecific variation. Heredity 55:307-313.

McDonald, J.A. and D.F. Austin. 1992. Changes and additions in Ipomoea section Batatas (Convolvulaceae). Brittonia 42:116-120.

Michelson, M.J., H.J. Price, J.R. Ellison, and J.S. Johnston. 1991.
Comparison of plant DNA contents determined by Feulgen microspectrophotometry and laser flow cytometry. Amer. J. Bet. 78:183-188.

Nishiyama, I. 1971. Evolution and domestication of the sweet potato. Bet. Msg. 84:377-387.

Orjeda, G., R. Freyre, and M. Iwanaga. 1990. Production of $2 n$ pollen in diploid Ipomoea trifida, a putative wild ancestor of sweet potato. J. Hered. 81:462-467.

Ortiz,R., D.E. Costich, T.P. Meagher, and N. Versa. 1992. Nuclear DNA content in blueberry determined by flow cytometry. HortScience 27:580. (Abstr.)

Price, H.J. 1988. DNA content variation among higher plants. Ann. Missouri Bet. Garden 75: 1248-1257.

Raybum, A.L. and J.A. Auger. 1990. Genome size variation in Zea mays ssp. mays adapted to different altitudes. Theoretical Applied Genet. 79:470-474.

Raybum, A. L., J.A. Auger, E.A. Benzinger, and A.G. Hepburn. 1989. Detection of intraspecific DNA content variation in Zea mays L. by flow cytometry. J. Expt. Bot. 40: 1179-1 183.

Shiotani, I. and T. Kawase. 1989. Genomic structure of the sweet potato and hexaploids in Ipomoea trifida (H.B.K) Don. Jpn. J. Breeding 39:57-66.

Sgorbati, S., E. Sparvoli, M. Levi, D. Chiatante, and P. Giordano. 1988. Bivariate cytofluorimetric analysis of DNA and nuclear protein content in plant tissue. Protoplasm 144:180-184.

Vindelov, L.L., I.J. Christensen, N. Keiding, M. Spang-Thomsen, and N.I. Nissen. 1982. Long-term storage of samples for flow cytometric DNA analysis. Cytometry 3:317-322. 